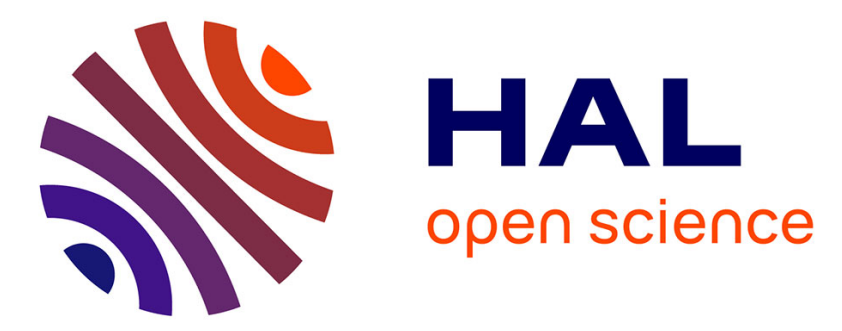

\title{
Different alterations of agonist and antagonist binding to 5-HT1A receptor in a rat model of Parkinson's disease and levodopa-induced dyskinesia: a microPET study
} Benjamin Vidal, Elise Levigoureux, Sarah Chaib, Caroline Bouillot, Thierry Billard, Adrian Newman-Tancredi, Luc Zimmer

\section{To cite this version:}

Benjamin Vidal, Elise Levigoureux, Sarah Chaib, Caroline Bouillot, Thierry Billard, et al.. Different alterations of agonist and antagonist binding to 5-HT1A receptor in a rat model of Parkinson's disease and levodopa-induced dyskinesia: a microPET study. Journal of Parkinson's disease, 2021, 11 (3), pp.1257-1269. 10.3233/JPD-212580 . hal-03407557

\section{HAL Id: hal-03407557 \\ https://hal.science/hal-03407557}

Submitted on 28 Oct 2021

HAL is a multi-disciplinary open access archive for the deposit and dissemination of scientific research documents, whether they are published or not. The documents may come from teaching and research institutions in France or abroad, or from public or private research centers.
L'archive ouverte pluridisciplinaire HAL, est destinée au dépôt et à la diffusion de documents scientifiques de niveau recherche, publiés ou non, émanant des établissements d'enseignement et de recherche français ou étrangers, des laboratoires publics ou privés. 
1 Different alterations of agonist and antagonist binding to $5-\mathrm{HT}_{1 \mathrm{~A}}$ receptor

2 in a rat model of Parkinson's disease and levodopa-induced dyskinesia : a Benjamin Vidal ${ }^{1, \#}$ Elise Levigoureux ${ }^{1,2, \#}$, Sarah Chaib $^{1,2}$, Caroline Bouillot ${ }^{3}$, Thierry Billard $^{3,4}$, Adrian Newman-Tancredi ${ }^{5}$, Luc Zimmer 1,2,3 *

${ }^{1}$ Université de Lyon, Université Claude Bernard Lyon 1, Lyon Neuroscience Research Center, CNRS UMR5292, INSERM U1028, Lyon, France.

${ }^{3}$ CERMEP-Imaging Platform, Bron, France.

${ }^{4}$ Institute of Chemistry and Biochemistry, Université de Lyon, CNRS, Villeurbanne, France

\# Authors that contributed equally to this work

* Corresponding author: Prof. Luc Zimmer; email: luc.zimmer@univ-lyon1.fr; phone: +33 4

Running title: 5- $\mathrm{HT}_{1 \mathrm{~A}} \mathrm{R}$ agonist and antagonist binding in Parkinson's disease and LID

Key words: 5-HT $1 \mathrm{~A}$; Parkinson's disease; serotonin; Levodopa-induced dyskinesia; GPCR 


\section{Abstract:}

BACKGROUND : The gold-standard treatment for Parkinson's disease is L-DOPA, which in the long term often leads to levodopa-induced dyskinesia. Serotonergic neurons are partially responsible for this, by converting L-DOPA into dopamine before uncontrolled release as a "false neurotransmitter". The stimulation of $5-\mathrm{HT}_{1 \mathrm{~A}}$ receptors can reduce involuntary movements but this mechanism is poorly understood.

OBJECTIVES : This study aimed to investigate the functionality of 5- $\mathrm{HT}_{1 \mathrm{~A}}$ receptor using positron emission tomography in hemiparkinsonian rats with or without dyskinesia induced by 3-weeks daily treatment with L-DOPA. Imaging sessions were performed “off” L-DOPA.

METHODS : Each rat underwent a positron emission tomography scan with $\left[{ }^{18} \mathrm{~F}\right] \mathrm{F} 13640$, a 5$\mathrm{HT}_{1 \mathrm{~A}} \mathrm{R}$ agonist (which labels receptors in a high affinity state for agonists) or [ $\left.{ }^{18} \mathrm{~F}\right] \mathrm{MPPF}$, a 5$\mathrm{HT}_{1 \mathrm{~A}} \mathrm{R}$ antagonist (which labels all the receptors).

RESULTS: There were decreases of $\left[{ }^{18} \mathrm{~F}\right] \mathrm{MPPF}$ binding in hemiparkinsonian rats in cortical areas. In dyskinetic animals, changes were slighter but also found in other regions. In hemiparkinsonian rats, $\left[{ }^{18} \mathrm{~F}\right] \mathrm{F} 13640$ uptake was decreased in the globus pallidus and thalamus. On the contralateral side, binding was increased in the insula, the hippocampus and the amygdala. In dyskinetic animals, $\left[{ }^{18} \mathrm{~F}\right] \mathrm{F} 13640$ binding was strongly increased in cortical and limbic areas, especially in the non-lesioned side.

CONCLUSION : These data suggest that agonist and antagonist $5-\mathrm{HT}_{1 \mathrm{~A}}$ receptor-binding sites are differently modified in Parkinson's disease and levodopa-induced dyskinesia. In particular, these observations suggest an important involvement of the functional state of $5-\mathrm{HT}_{1 \mathrm{~A}} \mathrm{R}$ in levodopa-induced dyskinesia and emphasize the need to characterize this state using agonist radiotracers in physiological and pathological conditions. 


\section{Introduction}

Parkinson's disease is a neurodegenerative disorder characterized by a wide variety of motor and non-motor symptoms. This disease affects approximately $1 \%$ of individuals older than 60 years and represents a major public health problem in developed countries [1]. At the onset of the disease, the gold-standard treatment for motor symptoms remains L-3,4dihydroxyphenylalanine (L-DOPA) [2]. This 'dopamine replacement' therapy is the most effective and the best tolerated in the short term [3-5]. However, long-term use of L-DOPA commonly leads to the development of debilitating dyskinesia known as levodopa-induced dyskinesia (LID) [6].

The pathological hallmark of Parkinson's disease is the loss of dopaminergic neurons in the substantia nigra pars compacta ( $\mathrm{SNc}$ ) and subsequent loss of dopamine release in the projection areas, but it is known that other monoaminergic systems are involved in the motor and nonmotor symptoms. Indeed, the serotonergic system plays an important role in the pathophysiology of the disease [7-9] and the appearance of LID.

Although the exact mechanisms are not completely elucidated, LID is associated with the conversion of L-DOPA into dopamine by serotonergic neurons and its aberrant striatal release as a 'false neurotransmitter' by lack of autoregulatory mechanisms [10,11]. Importantly, several studies have shown that activation of 5-HT $\mathrm{H}_{1 \mathrm{~A}}$ receptors decreases LID [12-16], which may be attributed to the inhibition of the 5 -HT system via the stimulation of $5-\mathrm{HT}_{1 \mathrm{~A}}$ autoreceptors (thereby reducing the release of dopamine by 5-HT terminals in the striatum). It should be noted that a direct activation of post-synaptic $5-\mathrm{HT}_{1 \mathrm{~A}}$ receptors in the striatum is also able to decrease LID $[17,18]$. 5-HT $\mathrm{H}_{1 \mathrm{~A}}$ receptor agonists have therefore been proposed as 
promising candidates for the treatment of LID, and may also be useful to treat motor or nonmotor symptoms of Parkinson's disease [19].

In this context, a better understanding of the pathophysiological role of this receptor in Parkinson's disease and LID seems critical to facilitate development of future treatments. To this end, several PET and autoradiography studies have been conducted using 5-HT $1 \mathrm{~A}$ receptor (5-HT HA $_{\text {A }}$ ) radioligands [20]. However, results have been inconsistent: some studies suggested an up-regulation[21-23], whereas others suggested a loss of 5-HT ${ }_{1 A} \mathrm{R}$ [24-26]. In addition, 5$\mathrm{HT}_{1 \mathrm{~A}} \mathrm{R}$ PET studies used antagonist radiotracers, such as $\left[{ }^{11} \mathrm{C}\right] \mathrm{WAY}-100635$ or $\left[{ }^{18} \mathrm{~F}\right] \mathrm{MPPF}$, and not agonist radiotracers. This is important because G protein-coupled receptors (GPCRs) such as $5-\mathrm{HT}_{1 \mathrm{~A}} \mathrm{R}$ can exist in a high or a low affinity states for agonists, depending on whether they are coupled or not to their $\mathrm{G}$ proteins [27]. Whereas $5-\mathrm{HT}_{1 \mathrm{~A}}$ receptor antagonists bind with equal affinity to coupled and uncoupled 5- $\mathrm{HT}_{1 \mathrm{~A}} \mathrm{R}$, agonists bind preferentially to the coupled receptors [28] in other words, to the active state of the receptor [29]. Thus, previous studies using antagonist radiotracers did not evaluate the functional state of 5- $\mathrm{HT}_{1 \mathrm{~A}} \mathrm{R}$ in Parkinson's disease. Given that GPCR coupling is potentially altered in pathological conditions [30-32] it seems critical to investigate the active state of $5-\mathrm{HT}_{1 \mathrm{~A}} \mathrm{R}$ in order to better understand their role in Parkinson's disease and LID [33].

We recently developed and validated in animal the first fluorinated agonist radiotracer of 5$\mathrm{HT}_{1 \mathrm{~A}}$ receptors, $\left[{ }^{18} \mathrm{~F}\right] \mathrm{F} 13640$ [34], and we have transferred it to humans as a new PET radiopharmaceutical [35]. This radiotracer is a full 5- $\mathrm{HT}_{1 \mathrm{~A}} \mathrm{R}$ agonist and displays a high affinity and selectivity for $5-\mathrm{HT}_{1 \mathrm{~A}}$ receptors $[36,37]$

Here, the aim was to investigate changes of $5-\mathrm{HT}_{1 \mathrm{~A}} \mathrm{R}$ coupling in the 6-OHDA-lesioned rat model of Parkinson's disease using both a $5-\mathrm{HT}_{1 \mathrm{~A}}$ antagonist radiotracer, $\left[{ }^{18} \mathrm{~F}\right] \mathrm{MPPF}$, and the 
agonist radiotracer $\left[{ }^{18}\right] \mathrm{F} 13640$. We also studied the functional state of $5-\mathrm{HT}_{1 \mathrm{~A}} \mathrm{R}$ in LID, using HPK rats that were chronically treated with L-DOPA.

\section{Methods}

\section{Animals}

Twenty-eight male Sprague-Dawley adult rats (Charles River laboratories, France) of $364.92 \pm 60.71 \mathrm{~g}$ were used. Animals were housed in standard temperature and humidity conditions with a 12h/12h light/dark cycle. Food and water were provided ad libitum. All experiments were performed in accordance with the European guidelines for care of laboratory animals (2010/63/EU) and approved by the University of Lyon review board.

\section{Unilateral 6-OHDA Lesions in the Medial Forebrain Bundle}

Rats were anesthetized using isoflurane. Prior to surgery, buprenorphine $(0.05 \mathrm{mg} / \mathrm{kg}$, s.c. $)$ was administered for peri- and post-surgical analgesia. Lidocain was used for local analgesia.

Rats were lesioned in the right medial forebrain bundle (MFB) according to the Paxinos and Watson's atlas [38] at coordinates $\mathrm{AP}=-4.0 \mathrm{~mm}, \mathrm{~L}=-1.3 \mathrm{~mm}, \mathrm{DV}=-7.6 \mathrm{~mm}$ relative to bregma and the dural surface by infusing 6-OHDA (Sigma Aldrich, MO, USA) $(14 \mu \mathrm{g} / 4 \mu \mathrm{L})$ dissolved in saline containing ascorbic acid (0.02\%). A volume of $4 \mu \mathrm{L}$ was injected over 5 min, leaving the microsyringe in situ for further $5 \mathrm{~min}$.

After 3 weeks, the rats were challenged with apomorphine $(0.05 \mathrm{mg} / \mathrm{kg}$, s.c.; Sigma-Aldrich $)$ and turning behavior assessed over $30 \mathrm{~min}$. The rats making $>10$ net full turns contralateral to 
the lesion were used in further experiments. This value was chosen in order to ensure a striatal dopamine depletion of at least $90 \%$ with no risk of false positives, as virtually no rotations are observed following apomorphine administration in the absence of such a lesion [39].

\section{Development of L-DOPA-induced motor behaviors}

For the study of LID, 6-OHDA lesioned rats received chronic daily treatment with L-DOPA (6 $\mathrm{mg} / \mathrm{kg})$ and benserazide $(12 \mathrm{mg} / \mathrm{kg})$ for 3 weeks in order to induce stable reproducible abnormal involuntary movements. After this induction phase, the rats were maintained with 2 injections of L-DOPA per week for the duration of the experiments (L-DOPA was not administered the days of imaging sessions, so that there was at least a 24 hour interval between an injection and the PET scan). Induction of LID was assessed by observing for one minute each rat at t: 20, 40, 60, 80, 100 120, 140, 160 and 180 min post L-DOPA administration, at day 1 (D1), day 7 (D7), day 14 (D14) and day 22 (D22) of treatment, using the following scale:

0: Absence of dyskinesia (normal)

1: Orolingual dyskinesia

2: Orolingual + moderate limb and axial dyskinesia

3: Orolingual + pronounced limb and axial dyskinesia.

\section{PET/CT imaging}

Animals were divided in three groups: 6-OHDA-lesioned rats (HPK; $n=7), 6-O H D A-l e s i o n e d$ rats with LID (HPK-LID; $n=9$ ) and control rats that had not been lesioned (CTRL; $n=12$ ). Animals either underwent 2 different PET scans with $\left[{ }^{18} \mathrm{~F}\right] \mathrm{MPPF}$ and $\left[{ }^{18} \mathrm{~F}\right] \mathrm{F} 13640$ (with a interval ranging from 2 to 19 days, and average of 7.7 days), or a single scan with either $\left[{ }^{18} \mathrm{~F}\right] \mathrm{MPPF}$ or $\left[{ }^{18} \mathrm{~F}\right] \mathrm{F} 13640$. Animals were scanned "off L-DOPA". For each scan, rats were 
anesthetized with $4-5 \%$ isoflurane for 5 min (induction phase), and a catheter was placed into their caudal vein. Anesthesia was then lowered to $2 \%$ isoflurane during the acquisition on the PET/CT (Inveon ${ }^{\circledR,}$ Siemens, Knoxville, TN, USA), with monitoring of the respiratory rate using a pressure sensor. The acquisition started with a CT image acquisition for $10 \mathrm{~min}$, followed by the intravenous injection of $\left[{ }^{18} \mathrm{~F}\right] \mathrm{MPPF}(14.01 \pm 2.30 \mathrm{MBq})$ or $\left[{ }^{18} \mathrm{~F}\right] \mathrm{F} 13640(12.14 \pm 2.68$ $\mathrm{MBq}$ ). The total duration of the scan was $60 \mathrm{~min}$. The images were reconstructed in three dimensions in a series of 24 sequential frames of increasing duration from $10 \mathrm{~s}$ to $5 \mathrm{~min}$. Regions of Interest (ROIs) were automatically delineated using a multi-atlas dataset [40], after manual positioning of the PET images on an anatomical MRI template using the software Inveon Research Workplace (IRW, Siemens). Distribution volume ratio (DVR) was estimated using Logan graphical method with reference region (cerebellum) calculated from 20 to 60 min in each region of interest (ROI) [41].

Concerning the voxel-based analysis, data processing was carried out using the statistical parametric mapping software (SPM12, Wellcome Trust Center for Neuroimaging, London; UK). Parametric images of Binding Potential Non-displaceable $\left(\mathrm{BP}_{\mathrm{ND}}\right)$ were generated for all rats using the Logan graphical method with reference region (cerebellum) calculated from 20 to 60 min. Individual PET images were realigned and spatially normalized on a custom PET template for each radiotracer which was coregistered on an anatomical MRI template. The quality of the registration was visually checked between all images to verify that they fitted well together and matched the MRI template in terms of cortical boundaries. Each PET volume was smoothed using an isotropic Gaussian filter [1.4 x $1.4 \times 1.4 \mathrm{~mm}]$.

\section{Statistical analyses}


For the comparisons of DVR in the regions of interest, a two-way ANOVA with Tukey's multiple comparisons test was performed ( $\mathrm{p}<0.05$, two-tailed).

The comparisons of parametric images between the different groups of animals were performed voxel by voxel using a t test analysis with a significance threshold set at $\mathrm{p}<0.01$ (uncorrected).

\section{Results}

\section{Development of L-DOPA-induced motor behaviors}

Six rats chronically treated with L-DOPA were scored as dyskinetic during the 60 min post LDOPA administration (peak effect): $2.3 \pm 0.2,2.7 \pm 0.2,2.5 \pm 0.2$ and $2.8 \pm 0.2$ (average dyskinetic score \pm SEM, at D1, D7, D14 and D22, respectively). The other rats from the group were also confirmed as dyskinetic but not systemically quantified.

\section{PET imaging of total 5-HT $T_{1 A}$ receptors using $\left[{ }^{18} \mathrm{~F}\right] M P P F$}

$\left[{ }^{18} \mathrm{~F}\right] \mathrm{MPPF}$ binding was compared between hemiparkinsonian rats with or without dyskinesia and control rats (Fig. 1). At the voxel level, $\left[{ }^{18} \mathrm{~F}\right] \mathrm{MPPF} \mathrm{BP}_{\mathrm{ND}}$ was significantly lower in hemiparkinsonian rats versus controls in various cortical areas, with few differences between the hemispheres (Fig. 1A). On the contrary, a local significant increase of $\left[{ }^{18} \mathrm{~F}\right] \mathrm{MPPF} \mathrm{BP}_{\mathrm{ND}}$ was found in the contralateral orbital cortex. In the ROIs (Fig. 1D), the most significant decreases of distribution volumes were found in the right and left hippocampus $(-11 \%, \mathrm{p}<0.0001$ and $8.5 \%, p=0.0009$ respectively). In the limbic system, the ipsilateral side of the amygdala was also affected $(-8.7 \%, \mathrm{p}=0.0407)$. Other ROIs with a decreased $\left[{ }^{18} \mathrm{~F}\right] \mathrm{MPPF}$ binding were cortical 
and bilateral (ranging from -15 to $-11 \%$ in the ipsilateral and from -9 to $-11 \%$ in the contralateral side), including the cingulate cortex, frontal cortex, occipital cortex and parietal cortex, but not the temporal cortex, where only the contralateral side was affected.

In the dyskinetic HPK rats, $\left[{ }^{18} \mathrm{~F}\right] \mathrm{MPPF}$ uptake was also modified in several areas (Fig. 1B). Fewer changes were found in the cortex, and were mainly located in the right somatosensory and motor cortices. Other decreases were found mainly in the limbic system: medial septum, lateral entorhinal cortex, and ventral hippocampus. $\left[{ }^{18} \mathrm{~F}\right] \mathrm{MPPF}$ uptake was also decreased in the right thalamus and the brainstem. Significant increases were found in the orbital cortex, similarly to HPK rats, but bilaterally. In the ROIs, significant decrease of DVR were found in ipsilateral side only in the hippocampus, the parietal cortex and the occipital cortex and ranged from -5 to $-9 \%$.

We also compared $\left[{ }^{18} \mathrm{~F}\right] \mathrm{MPPF}$ binding between HPK and HPK-LID rats (Fig. 1C). $\left[{ }^{18} \mathrm{~F}\right] \mathrm{MPPF}$ $\mathrm{BP}_{\mathrm{ND}}$ was significantly higher in non-dyskinetic animals in some areas of the limbic system (the medial septum and the entorhinal cortex), the median-raphe (median and magnus) and the dorsal thalamus (in green). On the contrary, $\left[{ }^{18} \mathrm{~F}\right] \mathrm{MPPF} \mathrm{BP}_{\mathrm{ND}}$ was higher in dyskinetic animals in parts of the parietal and occipital cortex, and the medial deepest part of the cerebellum (in brown). Results from the ROIs analysis also showed that $\left[{ }^{18} \mathrm{~F}\right] \mathrm{MPPF}$ uptake was higher in both sides of the hippocampus in the dyskinetic animals (Fig. 1D).

\section{PET imaging of 5-HT ${ }_{1 A}$ receptors in high-affinity state using $\left[{ }^{18} \mathrm{~F}\right] \mathrm{F} 13640$}

Binding potentials of $\left[{ }^{18} \mathrm{~F}\right] \mathrm{F} 13640$, reflecting changes in $5-\mathrm{HT}_{1 \mathrm{~A}}$ receptors in the high-affinity state for agonists, were compared between hemiparkinsonian rats with or without dyskinesia and control rats (Fig. 2). 
When comparing HPK and control rats (Fig. 2A), the voxel-based analysis revealed a significant decrease of $\left[{ }^{18} \mathrm{~F}\right] \mathrm{F} 13640$ binding potential in a large cluster of the ipsilateral hemisphere, spreading from the globus pallidus to the thalamus. A similar but smaller cluster was found on the contralateral side. HPK rats also displayed a higher $\left[{ }^{18} \mathrm{~F}\right] \mathrm{F} 13640$ binding in several limbic areas of the contralateral hemisphere, spreading from the insular cortex to the piriform cortex, the entorhinal cortex and parts of the hippocampus. When comparing the distribution volume ratios in the different regions of interest (Fig. 2D), we only found a significant decrease in the right thalamus in HPK rats versus control rats $(-11.5 \%, \mathrm{p}=0.0157)$.

Significant decreases of $\left[{ }^{18} \mathrm{~F}\right] \mathrm{F} 13640$ binding in HPK-LID rats were fewer than HPK rats (Fig. 2B); small clusters were found rostrally in the ventral thalamus, and caudally in the left substantia nigra, and parts of the cerebellum. On the contrary, many areas displayed a significant increase of binding potential. Similarly to HPK rats, most significant increases were located in areas of the limbic system, such as the piriform and entorhinal cortices, the amygdala and the ventral hippocampus. Other cortical regions were also affected, such as the prefrontal cortex and widespread areas of the temporal and parietal cortices. Other small increases were found in the hypothalamus and the brainstem. In general, increases were observed in both sides of the brain but were more significant in the contralateral hemisphere. Such increases were also significant when comparing the DVR between dyskinetic and control animals in several regions of interest (Fig. 2D), namely the left hippocampus $(+9.9 \%, p=0.0249)$, the right and left amygdala, cingulate cortex, and temporal cortex (ranging from +11 to $+12 \%$ in the ipsilateral side and from +12 to $+14 \%$ in the contralateral side).

We also compared voxel by voxel $\left[{ }^{18} \mathrm{~F}\right] \mathrm{F} 13640$ binding between HPK and HPK-LID rats (Fig. 2C). $\left[{ }^{18} \mathrm{~F}\right] \mathrm{F} 13640$ binding was significantly higher in dyskinetic animals (in brown) in various cortical areas in both hemispheres and the right striatum and thalamus. On the contrary, $\left[{ }^{18} \mathrm{~F}\right] \mathrm{F} 13640$ binding was higher in non-dyskinetic animals (in green) in the left substantia nigra 
and the paraflocculus of the cerebellum. In the regions of interest (Fig. 2D), DVR were higher in dyskinetic compared to non-dyskinetic rats in the right striatum $(+12.2 \%, p=0.0281)$, the right cingulate cortex $(+10.6 \%, \mathrm{p}=0.0321)$, and the right frontal cortex $(+12.6 \%, \mathrm{p}=0.0195)$.

\section{Discussion}

\section{5-HT $T_{1 A} R$ as a promising therapeutic target for Parkinson's disease?}

In addition to the dopaminergic system, it has been compellingly demonstrated that the serotonergic system is involved in the pathophysiology of Parkinson's disease, whether in terms of motor symptoms [24]; [42] or non-motor symptoms such as cognitive impairment [43] and mood disorders [44], but also in the etiology of LID $[45,46]$. In this context, the 5-HT ${ }_{1 A} R$ appears to be a promising therapeutic target: in addition to having a potential therapeutic effect in treating motor [47-50] and cognitive [51] symptoms or mood disorders [52-55] associated with Parkinson's disease, 5-HT $1 \mathrm{~A}$ agonists are highly effective for treating LID in preclinical models $[13,14,16,18,56-61]$. The main proposed mechanism for their antidyskinetic effects is the stimulation of autoreceptors in the raphe nuclei. However, striatal 5- $\mathrm{HT}_{1 \mathrm{~A}} \mathrm{R}$ may also play a role in control of LID $[17,62]$. There are also discrepancies regarding the effect of $5-\mathrm{HT}_{1 \mathrm{~A}}$ agonists on motor symptoms of Parkinson's disease [63-65]. Few clinical studies have been conducted with 5-HT $\mathrm{HT}_{1 \mathrm{~A}}$ agonists to treat LID, and reported either promising results [66-68] or worsening of parkinsonian features in a high proportion of patients [69].

Therefore, more information is needed to understand the mechanism of action of $5-\mathrm{HT}_{1 \mathrm{~A}}$ agonists in treating LID and how to diminish dyskinesia without worsening motor symptoms in patients. Indeed, little is currently known about the impact of Parkinson's disease and LID on $5-\mathrm{HT}_{1 \mathrm{~A}} \mathrm{R}$ levels and function. 

disease

261

We recently reported the radiosynthesis, preclinical validation [34] and first-in-man administration [35] of the first highly selective 5- $\mathrm{HT}_{1 \mathrm{~A}} \mathrm{R}$ full agonist PET radiotracer $\left[{ }^{18} \mathrm{~F}\right] \mathrm{F} 13640$. Unlike antagonist radiotracers of GPCRs, agonists radiotracers are known to bind preferentially to the receptors in a high-affinity state for agonists, that is, to receptors that are fully functional and accessible to the endogenous neurotransmitter [70-73]. We therefore investigated changes in $5-\mathrm{HT}_{1 \mathrm{~A}} \mathrm{R}$ in a rat model of Parkinson's disease using $\left[{ }^{18} \mathrm{~F}\right] \mathrm{F} 13640$ in comparison with an antagonist radiotracer, $\left[{ }^{18} \mathrm{~F}\right] \mathrm{MPPF}$. Furthermore, changes of $5-\mathrm{HT}_{1 \mathrm{~A}} \mathrm{R}$ levels and functionality were also studied in rats that were chronically treated with L-DOPA to elicit LID. Importantly, unlabeled F13640 (also known as befiradol or NLX-112) has shown promising antidyskinetic properties in rat, marmoset and macaque models of Parkinson's disease $[14,57,59]$. Therefore, the binding of $\left[{ }^{18} \mathrm{~F}\right] \mathrm{F} 13640$ points directly to the population of $5-\mathrm{HT}_{1 \mathrm{~A}} \mathrm{R}$ that are targeted by this antidyskinetic $5-\mathrm{HT}_{1 \mathrm{~A}}$ receptor agonist and is likely to provide important information regarding the therapeutic mechanism of this class of drugs.

Previous studies using antagonist radiotracers have shown disparate results. In rats that were unilaterally injected with 6-OH-DA in the striatum, binding potential of $\left[{ }^{18} \mathrm{~F}\right]$ Mefway was significantly lowered in the hippocampus $[74,75]$. In cynomolgus monkeys treated with 1methyl-4-phenyl-1,2,3,6-tetrahydropyridine (MPTP), $\left[{ }^{18} \mathrm{~F}\right] \mathrm{MPPF}$ binding was increased in various structures at early stages, whereas fewer changes were found in the fully symptomatic state [26]. An autoradiography study using $\left[{ }^{3} \mathrm{H}\right] \mathrm{WAY}-100635$ showed decreases of $5-\mathrm{HT}_{1 \mathrm{~A}} \mathrm{R}$ binding in the external layers and increases in the middle layers of the premotor and motor cortices of MPTP-lesioned macaques [21, 22]. 5- $\mathrm{HT}_{1 \mathrm{~A}} \mathrm{R}$ levels were also investigated in human studies using 5-HT $1 \mathrm{~A}$ antagonist radiotracers. In 2003, Doder et al. reported a decrease of $\left[{ }^{11} \mathrm{C}\right] \mathrm{WAY}-100635$ binding potential in the raphe of parkinsonian patients, which was 
significantly correlated with the tremor score [24]. Another study using $\left[{ }^{18} \mathrm{~F}\right] \mathrm{MPPF}$ showed decreases of 5-HT ${ }_{1 A} \mathrm{R}$ binding in patients, depending on the comorbidity with depression [26]. A postmortem autoradiography study reported an increased binding of $\left[{ }^{3} \mathrm{H}\right] \mathrm{WAY}-100635$ in the temporal cortex of patients [21]. These data show a complex involvement of $5-\mathrm{HT}_{1 \mathrm{~A}} \mathrm{R}$ in the pathophysiology of Parkinson's disease. The variability of these findings may be partly due to different species and models, but also by factors such disease progression, the development of dyskinesia or the chronic effects of L-DOPA treatment by itself. Indeed, long-term treatment with L-DOPA produces marked changes in the 5-HT system [76], as shown by a previous study showing increased tritiated WAY-100635 binding in MPTP-lesioned macaques chronically treated with L-DOPA compared with untreated macaques [22].

Once again, it should be emphasized that all the above studies used antagonist radiotracers to label 5-HT $\mathrm{H}_{1 \mathrm{~A}} \mathrm{R}$ : such tracers cannot characterize underlying changes in receptor-G-protein coupling state. In contrast, the use of the innovative agonist radiotracer, $\left[{ }^{18} \mathrm{~F}\right] \mathrm{F} 13640$, allowed us for the first time to examine changes in active state $5-\mathrm{HT}_{1 \mathrm{~A}} \mathrm{R}$ in the present model of Parkinson's disease.

PET imaging of high-affinity state 5-HT $T_{1 A}$ receptors allows revisiting the pathophysiology of LID

The main finding of this study is We found that the changes observed of the population of 5$\mathrm{HT}_{1 \mathrm{~A}} \mathrm{R}$ in the active (i.e. G-protein-coupled) state, as determined by $\left[{ }^{18} \mathrm{~F}\right] \mathrm{F} 13640$ binding, were completely distinct from the changes in the whole population of receptors, as visualized using $\left[{ }^{18} \mathrm{~F}\right] \mathrm{MPPF}$.

Using $\left[{ }^{18} \mathrm{~F}\right] \mathrm{MPPF}, 5-\mathrm{HT}_{1 \mathrm{~A}} \mathrm{R}$ binding appeared to be decreased in cortical areas only in HPK animals. In dyskinetic animals, the lower cortical binding was more restricted to the somatosensory, motor and entorhinal areas, but $\left[{ }^{18} \mathrm{~F}\right] \mathrm{MPPF}$ uptake was also lowered in 
subcortical areas such as the thalamus and the raphe. For both pathological groups, few increases were found and restricted to the orbital cortex.

Such changes occurring with a $5-\mathrm{HT}_{1 \mathrm{~A}} \mathrm{R}$ antagonist radiotracer are unlikely to be related to the functional state of receptors as they are known to bind equally to the coupled or uncoupled receptors [28], or to the competition with endogenous serotonin as $\left[{ }^{18} \mathrm{~F}\right] \mathrm{MPPF}$ is poorly sensitive to supraphysiological changes in serotonin concentration [34]. Therefore, cortical decreases of $\left[{ }^{18} \mathrm{~F}\right] \mathrm{MPPF}$ binding potential could be related to an altered affinity for receptors or to a lower density of 5- $\mathrm{HT}_{1 \mathrm{~A}}$ receptors, which could be related to various non-motors symptoms of Parkinson's disease such as cognitive impairment, depression and anxiety [43,44], as well as to motor and sensory deficits, since the somatosensory and motor cortices also displayed a decreased uptake. Another worthy observation is that in the raphe, $\left[{ }^{18} \mathrm{~F}\right] \mathrm{MPPF}$ binding was decreased in dyskinetic rats, which would suggest a decreased serotonergic autoinhibition that could be related to the dyskinetic behavior (as conversely, the stimulation of $5-\mathrm{HT}_{1 \mathrm{~A}}$ autoreceptors is able to block LID). Interestingly, the local increase in the ventral orbital cortex is consistent with a previous autoradiography study using a 5- $\mathrm{HT}_{1 \mathrm{~A}}$ antagonist radiotracer that showed an increased binding in the most internal parts of the frontal cortex in parkinsonian primates that were also chronically treated with L-DOPA [21], which was suggested to be linked to the visual hallucinations symptoms.

Numerous changes of $\left[{ }^{18} \mathrm{~F}\right] \mathrm{F} 13640$ uptake were also found in HPK and dyskinetic rats. These changes are more difficult to interpret but also more reflective of the pathophysiological involvement of 5- $\mathrm{HT}_{1 \mathrm{~A}} \mathrm{R}$, as contrary to antagonists, agonists bind preferentially to the active state, i.e., G-protein coupled state of receptors, $[28,77]$. This means that an increased proportion of receptors in the uncoupled state could lead to a decrease in $\left[{ }^{18} \mathrm{~F}\right] \mathrm{F} 13640$ binding. Another important consideration is that $\left[{ }^{18} \mathrm{~F}\right] \mathrm{F} 13640$ was shown to be very sensitive to the competition with endogenous serotonin [34], therefore a local increase in serotonin concentration could also 
lead to a decrease in $\left[{ }^{18} \mathrm{~F}\right] \mathrm{F} 13640$ binding. As seen in the voxel analysis, $\left[{ }^{18} \mathrm{~F}\right] \mathrm{F} 13640$ binding modifications were spatially distinct from that of $\left[{ }^{18} \mathrm{~F}\right] \mathrm{MPPF}$, therefore we propose that they were mainly due one or both of these mechanisms (intracellular coupling or extracellular serotonin concentration) rather than changes in the density of receptors (which should also be observed using $\left.\left[{ }^{18} \mathrm{~F}\right] \mathrm{MPPF}\right)$.

In HPK rats, $\left[{ }^{18} \mathrm{~F}\right] \mathrm{F} 13640$ uptake was decreased in the globus pallidus and the thalamus, especially in the lesioned side. There might be an increased serotonergic innervation in these areas, which would be consistent with a recent study in MPTP-lesioned cynomolgus monkeys showing a 2-fold increase of serotonergic axon varicosities in the globus pallidus [78]. Alternatively, 5- $\mathrm{HT}_{1 \mathrm{~A}} \mathrm{R}$ coupling state might be altered in this region, which is supported by very recent findings in 6-OHDA lesioned rats showing that $5-\mathrm{HT}_{1 \mathrm{~A}}$ agonists effects are decreased in the entopeduncular nucleus (which is analogous to the internal part of the globus pallidus) compared to control rats [79]. In the contralateral side, $\left[{ }^{18} \mathrm{~F}\right] \mathrm{F} 13640$ uptake was increased in limbic areas or limbic-related areas such as the insula, the entorhinal cortex, and the amygdala and the ventral hippocampus. Such increases could be due to the loss of serotonergic neurons in Parkinson's disease [80] as they were observed in areas richly innervated by 5 -HT, although it is unclear why they were more pronounced in the non-lesioned side. This deserves more investigation in the future to understand if these increases are the signature of a compensatory mechanism and how they are involved in non-motor symptoms of Parkinson's disease; given that they occur in limbic regions, they may be linked to the cognitive and mood symptoms.

Interestingly, dyskinetic animals displayed more pronounced increases of $\left[{ }^{18} \mathrm{~F}\right] \mathrm{F} 13640$ binding in the same regions as non-dyskinetic HPK animals but that also spread to cortical areas, and to the ipsilateral side of the brain. These observations are consistent with the known involvement of the serotonergic system in LID and could be due to a possible decrease of 5-HT 
basal levels in many regions in dyskinetic animals. The decreased 5-HT concentration would acutely result in a decreased competition towards $5-\mathrm{HT}_{1 \mathrm{~A}} \mathrm{R}$ and higher binding of $\left[{ }^{18} \mathrm{~F}\right] \mathrm{F} 13640$, but it can also be expected that a chronic depletion of 5-HT release would result in an overexpression of $5-\mathrm{HT}_{1 \mathrm{~A}} \mathrm{R}$ in the high-affinity state as a compensatory mechanism due to the chronic lack of stimulation by 5-HT. Indeed, it has been shown in 6-OH-DA-lesioned rats that L-DOPA decreases extracellular concentration of serotonin in the prefrontal cortex and hippocampus after acute administration [81] and decreases basal extracellular 5-HT levels in the PFC, striatum, hippocampus and substantia nigra after chronic administration [82]. Deficits in 5-HT release can arise from several mechanisms [83]: first, after decarboxylation of L-DOPA in 5-HT neurons, dopamine competes with 5-HT for storage into vesicles and exocytotic release $[10,84]$; secondly, L-DOPA treatment can induce oxidative stress that is known to induce 5HT neuron loss in vivo in HPK rats [85]. Our data are consistent with the reported deleterious effect of chronic L-DOPA treatment on 5-HT system, that would have repercussions at the postsynaptic level: the regions where increased levels of active $5-\mathrm{HT}_{1 \mathrm{~A}} \mathrm{R}$ were observed are known to be highly innervated by 5-HT neurons, probably reflecting a compensatory phenomenon following the lack of stimulation of $5-\mathrm{HT}_{1 \mathrm{~A}} \mathrm{R}$ by extracellular serotonin. Questions remain to be elucidated regarding some regions where $\left[{ }^{18} \mathrm{~F}\right] \mathrm{F} 13640$ binding was lower, such as the left substantia nigra. Although one study reported that chronic treatment with L-DOPA also decreased 5-HT levels in this region [82], another study reported increased 5-HT release in substantia nigra in awake rats chronically treated with L-DOPA [86]. Thus, L-DOPA administration may have distinctive effects on 5-HT neurotransmission in this specific region, as suggested by a microdialysis study which showed a strong increase of 5-HT release (13-fold) after local injection of L-DOPA in substantia nigra [87]. Anyway, only the contralateral side of substantia nigra was affected in our study, which suggests that dopamine neurons must be involved in this local decrease. Taken together, these findings show that the high-affinity state 
of 5-HT $\mathrm{H}_{1 \mathrm{~A}} \mathrm{R}$ is even further modified by chronic L-DOPA treatment and dyskinesia, which may be related to the non-motors symptoms that can be related to the serotonergic projections areas such as the limbic system and prefrontal cortex (that is, mainly cognitive processes, anxiety and mood disorders). Indeed, there is evidence that L-DOPA can worsen these symptoms in the long term [88].

Another important result of our study is the increase of $\left[{ }^{18} \mathrm{~F}\right] \mathrm{F} 13640$ uptake in the lesioned striatum in dyskinetic animals compared to untreated animals. This could be explained by a lower serotonergic innervation of the lesioned striatum in dyskinetic animals, resulting in higher binding of the radiotracer, but this hypothesis is contradicted by a previous study which showed that L-DOPA chronic treatment in HPK rats results in a higher SERT binding density in the lesioned striatum [89]. Therefore, this is more likely reflecting a switching of a striatal population of $5-\mathrm{HT}_{1 \mathrm{~A}} \mathrm{R}$ in the high-affinity state, suggesting a hypersensitivity of $5-\mathrm{HT}_{1 \mathrm{~A}} \mathrm{R}$ in the lesioned side of the striatum.

As previously discussed, changes occurring at the level of presynaptic serotonergic transmission could explain some of our results with $\left[{ }^{18} \mathrm{~F}\right] \mathrm{F} 13640$. In the future, it would be valuable to evaluate the changes of $\left[{ }^{18} \mathrm{~F}\right] \mathrm{F} 13640$ along with the extracellular 5-HT concentration and the level of serotonin transporter. This is also important as the injection of 6-OHDA could induce serotonergic lesions, although we observed marked changes in the contralateral side of the brain, which would not be directly impacted by the toxin.

Finally, our results demonstrate that the coupling state of $5-\mathrm{HT}_{1 \mathrm{~A}} \mathrm{R}$ can be strongly disrupted in Parkinson's disease and LID, supporting the use of agonist radiotracers in future clinical PET studies to revisit the pathophysiological involvement of these receptors. Such studies would contribute to a better understanding of the role of $5-\mathrm{HT}_{1 \mathrm{~A}} \mathrm{R}$ in the psychiatric and motor symptoms in Parkinson's disease. Focusing on the active state of 5- $\mathrm{HT}_{1 \mathrm{~A}} \mathrm{R}$ may also constitute 
408 a biomarker for monitoring disease progression, or for measuring occupancy changes after 409 administration of clinical doses of $5-\mathrm{HT}_{1 \mathrm{~A}}$ agonists $\left(5-\mathrm{HT}_{1 \mathrm{~A}} \mathrm{R}\right.$ antagonist radiotracers being 410 poorly sensitive to competition with agonists - see [90-94]). Overall, the use of agonist PET 411 tracers opens multiple avenues of investigation for brain imaging of Parkinson's disease and 412 other disorders involving serotonergic neurotransmission. 


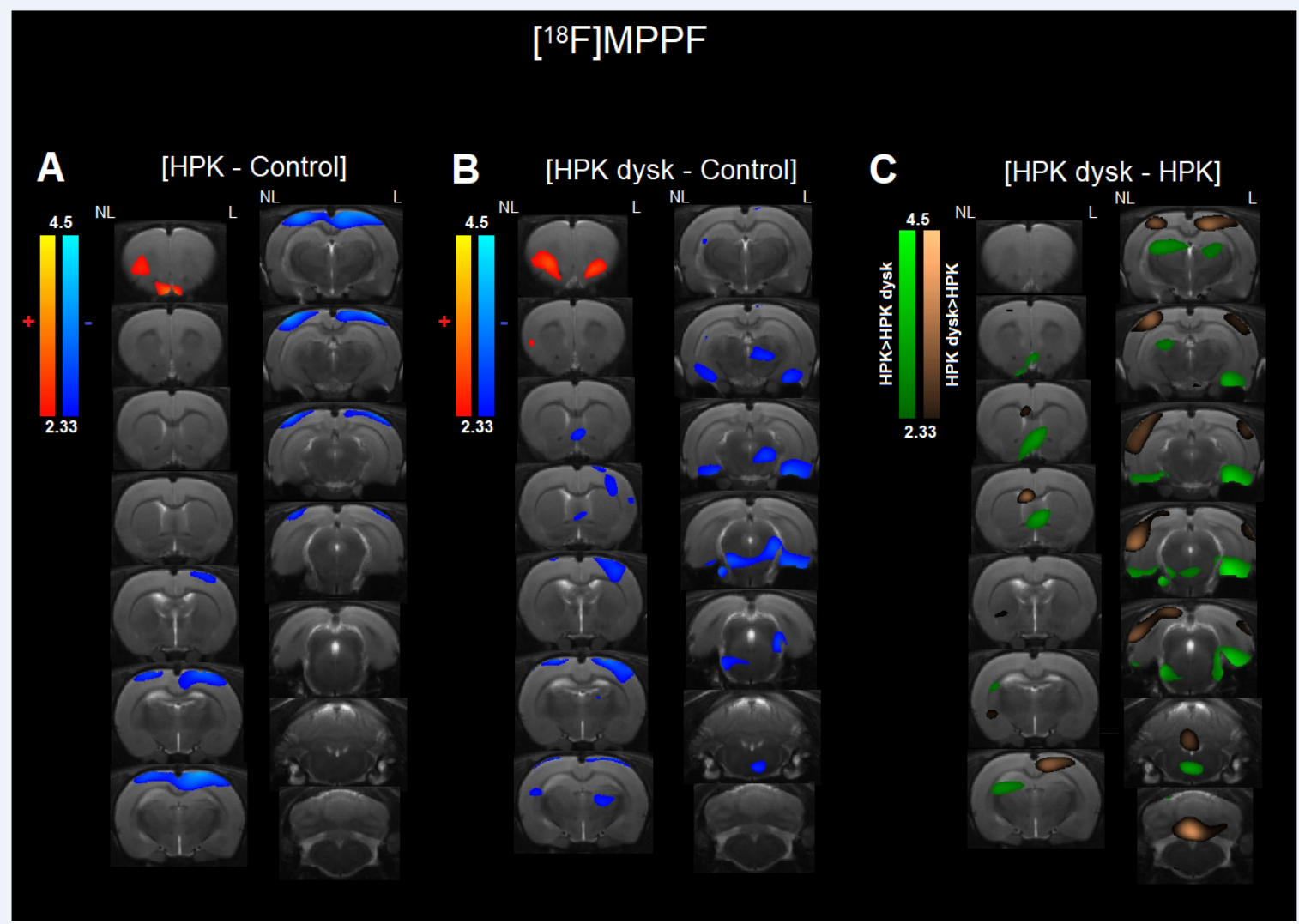

D

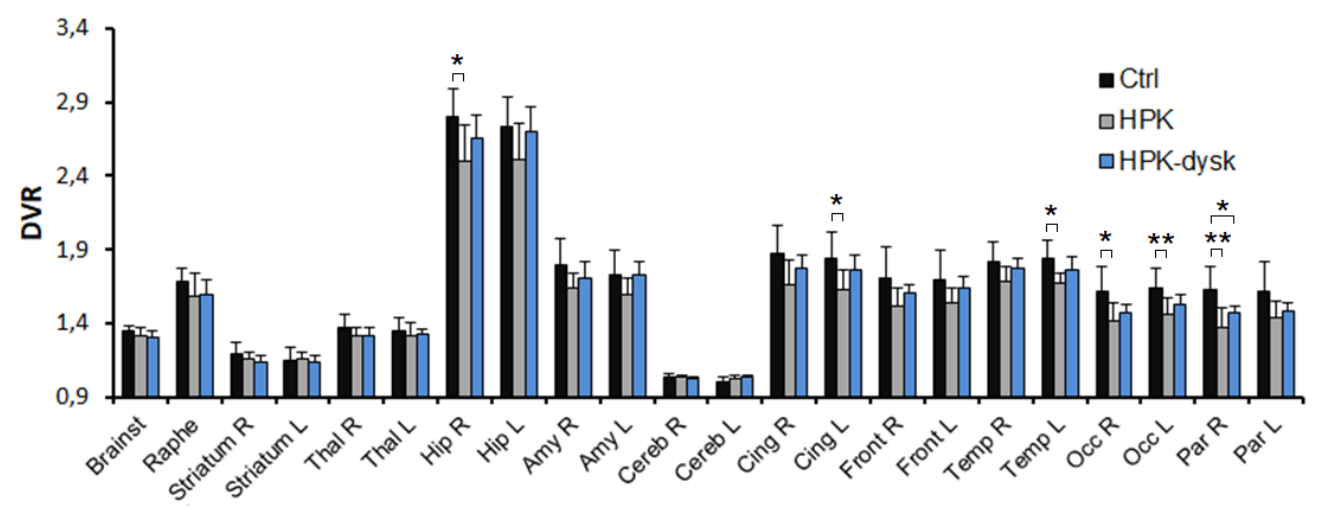



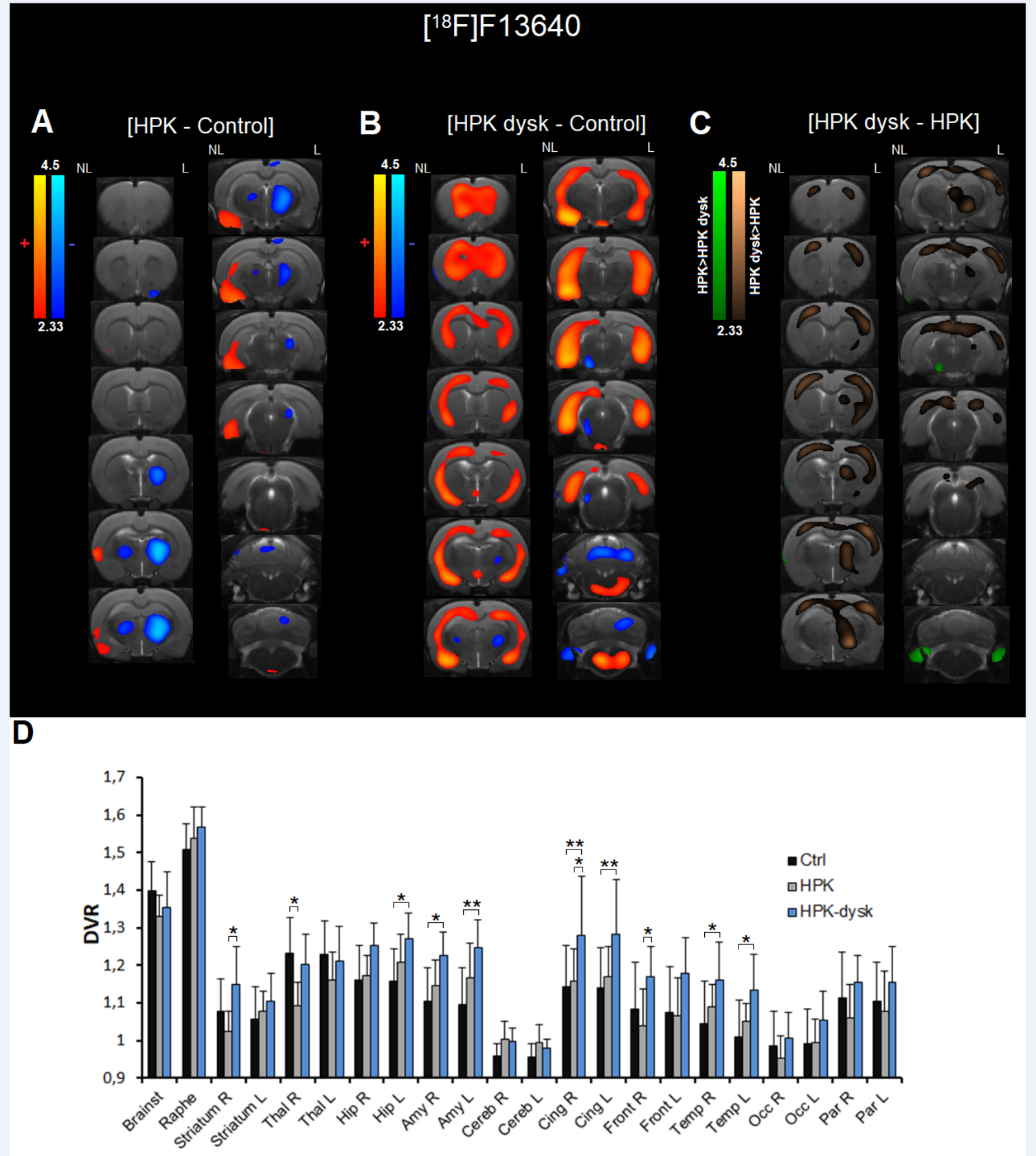
Figure 1: Effect of 6-OH-DA lesion and LID induction on $\left[{ }^{18}\right.$ F]MPPF PET imaging in rats.

A - Voxel-to-voxel statistical comparisons of $\left[{ }^{18} \mathrm{~F}\right] \mathrm{MPPF} \mathrm{BP}_{\mathrm{ND}}$ between control rats and hemiparkinsonian rats. $\mathrm{Z}$ scores in color scales (significant increases in red, significant decreases in blue; $\mathrm{p}<0.01)$. B - Voxel-to-voxel statistical comparisons of $\left[{ }^{18} \mathrm{~F}\right] \mathrm{MPPF} \mathrm{BP}_{\mathrm{ND}}$ between control rats and hemiparkinsonian rats that developed LID. Z scores in color scales (significant increases in red, significant decreases in blue; $\mathrm{p}<0.01$ ). C - Voxel-to-voxel statistical comparisons of $\left[{ }^{18} \mathrm{~F}\right] \mathrm{MPPF} \mathrm{BP}_{\mathrm{ND}}$ between hemiparkinsonian rats that developed LID and untreated hemiparkinsonian rats. $\mathrm{Z}$ scores in color scales (higher $\mathrm{BP}_{\mathrm{ND}}$ in non-dyskinetic rats in green, higher $\mathrm{BP}_{\mathrm{ND}}$ in dyskinetic rats in brown; $\left.\mathrm{p}<0.01\right)$. D - Mean DVR values $( \pm \mathrm{SD})$ in the different regions of interest for each group $\left({ }^{*} \mathrm{p}<0.05,{ }^{* *} \mathrm{p}<0.01\right)$.

\section{Figure 2: Effect of 6-OH-DA lesion and LID induction on $\left[{ }^{18} \mathrm{~F}\right] \mathrm{F} 13640$ PET imaging in} rats. A - Voxel-to-voxel statistical comparisons of $\left[{ }^{18} \mathrm{~F}\right] \mathrm{F} 13640 \mathrm{BP}_{\mathrm{ND}}$ between control rats and hemiparkinsonian rats. $\mathrm{Z}$ scores in color scales (significant increases in red, significant decreases in blue; $\mathrm{p}<0.01)$. B - Voxel-to-voxel statistical comparisons of $\left[{ }^{18} \mathrm{~F}\right] \mathrm{F} 13640 \mathrm{BP}_{\mathrm{ND}}$ between control rats and hemiparkinsonian rats that developed LID. Z scores in color scales (significant increases in red, significant decreases in blue; $\mathrm{p}<0.01$ ). C - Voxel-to-voxel statistical comparisons of $\left[{ }^{18} \mathrm{~F}\right] \mathrm{F} 13640 \mathrm{BP}$ ND between hemiparkinsonian rats that developed LID and untreated hemiparkinsonian rats. $\mathrm{Z}$ scores in color scales (higher $\mathrm{BP}_{\mathrm{ND}}$ in nondyskinetic rats in green, higher $\mathrm{BP}_{\mathrm{ND}}$ in dyskinetic rats in brown; $\mathrm{p}<0.01$ ). $\mathrm{D}-$ Mean DVR values $( \pm \mathrm{SD})$ in the different regions of interest for each group $\left({ }^{*} \mathrm{p}<0.05,{ }^{*} \mathrm{p}<0.01\right)$. 
444 We thank Ronan Depoortere for his contribution in the animal behavioural analyses, Jérôme

445 Redouté and Nicolas Costes for their help in the data analysis and Véronique Gualda for the 446 zootechnical assistance.

\section{Conflict of Interest}

448 Dr. Newman-Tancredi is an employee and stockholder of Neurolixis.

449 The other authors have no conflict of interest to report.

450 
452 [1] de Lau LM, Breteler MM (2006) Epidemiology of Parkinson's disease. Lancet Neuro/ 5, 525-

[2] Fahn S (2008) How do you treat motor complications in Parkinson's disease: Medicine, surgery, or both? Ann Neurol 64 Suppl 2, S56-64.

[3] Poewe W, Seppi K, Tanner CM, Halliday GM, Brundin P, Volkmann J, Schrag AE, Lang AE (2017) Parkinson disease. Nat Rev Dis Primers 3, 17013.

[4] Poewe W (2017) Parkinson's disease and the quest for preclinical diagnosis: an interview with Professor Werner Poewe. Neurodegener Dis Manag 7, 273-277.

[5] Poewe W, Seppi K (2017) Insulin signalling: new target for Parkinson's treatments? Lancet 390, 1628-1630.

[6] Marsden CD, Parkes JD (1977) Success and problems of long-term levodopa therapy in Parkinson's disease. Lancet 1, 345-349.

[7] Politis M, Niccolini F (2015) Serotonin in Parkinson's disease. Behav Brain Res 277, 136-145.

[8] Ohno Y, Shimizu S, Tokudome K, Kunisawa N, Sasa M (2015) New insight into the therapeutic role of the serotonergic system in Parkinson's disease. Prog Neurobiol 134, 104-121.

[9] Mahmoudi J, Farhoudi M, Reyhani-Rad S, Sadigh-Eteghad S (2013) Dampening of Serotonergic System through 5HT1A Receptors is a Promising Target for Treatment of Levodopa Induced Motor Problems. Adv Pharm Bull 3, 439-441.

[10] Carta M, Carlsson T, Kirik D, Bjorklund A (2007) Dopamine released from 5-HT terminals is the cause of L-DOPA-induced dyskinesia in parkinsonian rats. Brain 130, 1819-1833.

[11] Cenci MA (2014) Presynaptic Mechanisms of I-DOPA-Induced Dyskinesia: The Findings, the Debate, and the Therapeutic Implications. Front Neurol 5, 242.

[12] Freitas ME, Fox SH (2016) Nondopaminergic treatments for Parkinson's disease: current and future prospects. Neurodegener Dis Manag 6, 249-268.

[13] Farajdokht F, Sadigh-Eteghad S, Majdi A, Pashazadeh F, Vatandoust SM, Ziaee M, Safari F, Karimi P, Mahmoudi J (2020) Serotonergic system modulation holds promise for L-DOPAinduced dyskinesias in hemiparkinsonian rats: A systematic review. EXCLI J 19, 268-295.

[14] Iderberg H, McCreary AC, Varney MA, Kleven MS, Koek W, Bardin L, Depoortere R, Cenci MA, Newman-Tancredi A (2015) NLX-112, a novel 5-HT1A receptor agonist for the treatment of LDOPA-induced dyskinesia: Behavioral and neurochemical profile in rat. Exp Neurol 271, 335350.

[15] Iderberg H, Maslava N, Thompson AD, Bubser M, Niswender CM, Hopkins CR, Lindsley CW, Conn PJ, Jones CK, Cenci MA (2015) Pharmacological stimulation of metabotropic glutamate receptor type 4 in a rat model of Parkinson's disease and L-DOPA-induced dyskinesia: Comparison between a positive allosteric modulator and an orthosteric agonist. Neuropharmacology 95, 121-129.

[16] Iderberg H, McCreary AC, Varney MA, Cenci MA, Newman-Tancredi A (2015) Activity of serotonin 5-HT(1A) receptor 'biased agonists' in rat models of Parkinson's disease and LDOPA-induced dyskinesia. Neuropharmacology 93, 52-67.

[17] Bishop C, Krolewski DM, Eskow KL, Barnum CJ, Dupre KB, Deak T, Walker PD (2009) Contribution of the striatum to the effects of 5-HT1A receptor stimulation in L-DOPA-treated hemiparkinsonian rats. J Neurosci Res 87, 1645-1658.

[18] Meadows SM, Chambers NE, Conti MM, Bossert SC, Tasber C, Sheena E, Varney M, NewmanTancredi A, Bishop C (2017) Characterizing the differential roles of striatal 5-HT1A auto- and hetero-receptors in the reduction of I-DOPA-induced dyskinesia. Exp Neurol 292, 168-178.

[19] Shimizu S, Ohno Y (2013) Improving the Treatment of Parkinson's Disease: A Novel Approach by Modulating 5-HT(1A) Receptors. Aging Dis 4, 1-13.

[20] Pagano G, Politis M (2018) Molecular Imaging of the Serotonergic System in Parkinson's Disease. Int Rev Neurobiol 141, 173-210. 
[21] Huot P, Johnston TH, Visanji NP, Darr T, Pires D, Hazrati LN, Brotchie JM, Fox SH (2012) Increased levels of 5-HT1A receptor binding in ventral visual pathways in Parkinson's disease. Mov Disord 27, 735-742.

[22] Huot P, Johnston TH, Koprich JB, Winkelmolen L, Fox SH, Brotchie JM (2012) Regulation of cortical and striatal 5-HT1A receptors in the MPTP-lesioned macaque. Neurobiol Aging 33, 207 e209-219.

[23] Ballanger B, Beaudoin-Gobert M, Neumane S, Epinat J, Metereau E, Duperrier S, Broussolle E, Thobois S, Bonnefoi F, Tourvielle C, Lavenne F, Costes N, Lebars D, Zimmer L, SgambatoFaure V, Tremblay L (2016) Imaging Dopamine and Serotonin Systems on MPTP Monkeys: A Longitudinal PET Investigation of Compensatory Mechanisms. J Neurosci 36, 1577-1589.

[24] Doder M, Rabiner EA, Turjanski N, Lees AJ, Brooks DJ, study CWP (2003) Tremor in Parkinson's disease and serotonergic dysfunction: an 11C-WAY 100635 PET study. Neurology 60, 601-605.

[25] Lee JY, Seo S, Lee JS, Kim HJ, Kim YK, Jeon BS (2015) Putaminal serotonergic innervation: monitoring dyskinesia risk in Parkinson disease. Neurology 85, 853-860.

[26] Ballanger B, Klinger H, Eche J, Lerond J, Vallet AE, Le Bars D, Tremblay L, Sgambato-Faure V, Broussolle $E$, Thobois $S$ (2012) Role of serotonergic $1 A$ receptor dysfunction in depression associated with Parkinson's disease. Mov Disord 27, 84-89.

[27] Mongeau R, Welner SA, Quirion R, Suranyi-Cadotte BE (1992) Further evidence for differential affinity states of the serotonin1A receptor in rat hippocampus. Brain Res 590, 229-238.

[28] Gozlan H, Thibault S, Laporte AM, Lima L, Hamon M (1995) The selective 5-HT1A antagonist radioligand [3H]WAY 100635 labels both G-protein-coupled and free 5-HT1A receptors in rat brain membranes. Eur J Pharmacol 288, 173-186.

[29] Aznavour N, Rbah L, Leger L, Buda C, Sastre JP, Imhof A, Charnay Y, Zimmer L (2006) A comparison of in vivo and in vitro neuroimaging of 5-HT $1 \mathrm{~A}$ receptor binding sites in the cat brain. J Chem Neuroanat 31, 226-232.

[30] Avissar S, Schreiber G (2006) The involvement of $G$ proteins and regulators of receptor-G protein coupling in the pathophysiology, diagnosis and treatment of mood disorders. Clin Chim Acta 366, 37-47.

[31] Becker G, Streichenberger N, Billard T, Newman-Tancredi A, Zimmer L (2014) A postmortem study to compare agonist and antagonist 5-HT1A receptor-binding sites in Alzheimer's disease. CNS Neurosci Ther 20, 930-934.

[32] Vidal B, Sebti J, Verdurand M, Fieux S, Billard T, Streichenberger N, Troakes C, NewmanTancredi A, Zimmer L (2016) Agonist and antagonist bind differently to 5-HT1A receptors during Alzheimer's disease: A post-mortem study with PET radiopharmaceuticals. Neuropharmacology 109, 88-95.

[33] Zimmer L (2016) Pharmacological agonists for more-targeted CNS radio-pharmaceuticals. Oncotarget 7, 80111-80112.

[34] Vidal B, Fieux S, Colom M, Billard T, Bouillot C, Barret O, Constantinescu C, Tamagnan G, Newman-Tancredi A, Zimmer L (2018). 18F-F13640 preclinical evaluation in rodent, cat and primate as a 5-HT1A receptor agonist for PET neuroimaging. Brain Struct Funct 223,29732988.

[35] Colom M, Costes N, Redoute J, Dailler F, Gobert F, Le Bars D, Billard T, Newman-Tancredi A, Zimmer L (2020) (18)F-F13640 PET imaging of functional receptors in humans. Eur J Nucl Med Mol Imaging 47, 220-221.

[36] Colpaert FC, Tarayre JP, Koek W, Pauwels PJ, Bardin L, Xu XJ, Wiesenfeld-Hallin Z, Cosi C, Carilla-Durand E, Assie MB, Vacher B (2002) Large-amplitude 5-HT1A receptor activation: a new mechanism of profound, central analgesia. Neuropharmacology 43, 945-958.

[37] Newman-Tancredi A, Martel JC, Cosi C, Heusler P, Lestienne F, Varney MA, Cussac D (2017) Distinctive in vitro signal transduction profile of NLX-112, a potent and efficacious serotonin 5-HT1A receptor agonist. J Pharm Pharmacol 69, 1178-1190. 
[38] Paxinos G, Watson C (2013), p. 472.

[39] Hudson JL, van Horne CG, Stromberg I, Brock S, Clayton J, Masserano J, Hoffer BJ, Gerhardt GA (1993) Correlation of apomorphine- and amphetamine-induced turning with nigrostriatal dopamine content in unilateral 6-hydroxydopamine lesioned rats. Brain Res 626, 167-174.

[40] Lancelot S, Roche R, Slimen A, Bouillot C, Levigoureux E, Langlois JB, Zimmer L, Costes N (2014) A multi-atlas based method for automated anatomical rat brain MRI segmentation and extraction of PET activity. PLoS One 9, e109113.

[41] Logan J, Fowler JS, Volkow ND, Wang GJ, Ding YS, Alexoff DL (1996) Distribution volume ratios without blood sampling from graphical analysis of PET data. J Cereb Blood Flow Metab 16, 834-840.

[42] Vegas-Suarez S, Paredes-Rodriguez E, Aristieta A, Lafuente JV, Miguelez C, Ugedo L (2019) Dysfunction of serotonergic neurons in Parkinson's disease and dyskinesia. Int Rev Neurobiol 146, 259-279.

[43] O'Callaghan C, Lewis SJG (2017) Cognition in Parkinson's Disease. Int Rev Neurobiol 133, 557583.

[44] Gallagher DA, Schrag A (2012) Psychosis, apathy, depression and anxiety in Parkinson's disease. Neurobiol Dis 46, 581-589.

[45] Carta M, Bjorklund A (2018) The serotonergic system in L-DOPA-induced dyskinesia: preclinical evidence and clinical perspective. J Neural Transm (Vienna) 125, 1195-1202.

[46] Chagraoui A, Boulain M, Juvin L, Anouar Y, Barriere G, Deurwaerdere P (2019) L-DOPA in Parkinson's Disease: Looking at the "False" Neurotransmitters and Their Meaning. Int J Mol Sci 21.

[47] Bibbiani F, Oh JD, Chase TN (2001) Serotonin 5-HT1A agonist improves motor complications in rodent and primate parkinsonian models. Neurology 57, 1829-1834.

[48] Bezard E, Gerlach I, Moratalla R, Gross CE, Jork R (2006) 5-HT1A receptor agonist-mediated protection from MPTP toxicity in mouse and macaque models of Parkinson's disease. Neurobiol Dis 23, 77-86.

[49] Mignon L, Wolf WA (2007) Postsynaptic 5-HT1A receptor stimulation increases motor activity in the 6-hydroxydopamine-lesioned rat: implications for treating Parkinson's disease. Psychopharmacology (Berl) 192, 49-59.

[50] Matsubara K, Shimizu K, Suno M, Ogawa K, Awaya T, Yamada T, Noda T, Satomi M, Ohtaki K, Chiba K, Tasaki Y, Shiono H (2006) Tandospirone, a 5-HT1A agonist, ameliorates movement disorder via non-dopaminergic systems in rats with unilateral 6-hydroxydopamine-generated lesions. Brain Res 1112, 126-133.

[51] Depoortere R, Auclair AL, Bardin L, Colpaert FC, Vacher B, Newman-Tancredi A (2010) F15599, a preferential post-synaptic 5-HT1A receptor agonist: activity in models of cognition in comparison with reference 5-HT1A receptor agonists. Eur Neuropsychopharmacol 20,641654.

[52] Hui YP, Zhang QJ, Zhang L, Chen L, Guo Y, Qiao HF, Wang Y, Liu J (2014) Activation of prelimbic 5-HT1A receptors produces antidepressant-like effects in a unilateral rat model of Parkinson's disease. Neuroscience 268, 265-275.

[53] Hui YP, Wang T, Han LN, Li LB, Sun YN, Liu J, Qiao HF, Zhang QJ (2015) Anxiolytic effects of prelimbic 5-HT(1A) receptor activation in the hemiparkinsonian rat. Behav Brain Res 277, 211-220.

[54] Sun YN, Wang T, Wang Y, Han LN, Li LB, Zhang YM, Liu J (2015) Activation of 5-HT(1)A receptors in the medial subdivision of the central nucleus of the amygdala produces anxiolytic effects in a rat model of Parkinson's disease. Neuropharmacology 95, 181-191.

[55] Jiang YF, Liu J, Yang J, Guo Y, Hu W, Zhang J, La XM, Xie W, Wang HS, Zhang L (2020) Involvement of the Dorsal Hippocampus 5-HT1A Receptors in the Regulation of DepressiveLike Behaviors in Hemiparkinsonian Rats. Neuropsychobiology 79, 198-207.

[56] Huot P, Sgambato-Faure V, Fox SH, McCreary AC (2017) Serotonergic Approaches in Parkinson's Disease: Translational Perspectives, an Update. ACS Chem Neurosci 8, 973-986. 
[57] Fisher R, Hikima A, Morris R, Jackson MJ, Rose S, Varney MA, Depoortere R, NewmanTancredi A (2020) The selective 5-HT1A receptor agonist, NLX-112, exerts anti-dyskinetic and anti-parkinsonian-like effects in MPTP-treated marmosets. Neuropharmacology 167, 107997.

[58] Newman-Tancredi A, Varney MA, McCreary AC (2018) Effects of the Serotonin 5-HT1A Receptor Biased Agonists, F13714 and F15599, on Striatal Neurotransmitter Levels Following L-DOPA Administration in Hemi-Parkinsonian Rats. Neurochem Res 43, 1035-1046.

[59] McCreary AC, Varney MA, Newman-Tancredi A (2016) The novel 5-HT1A receptor agonist, NLX-112 reduces I-DOPA-induced abnormal involuntary movements in rat: A chronic administration study with microdialysis measurements. Neuropharmacology 105, 651-660.

[60] Dupre KB, Ostock CY, George JA, Eskow Jaunarajs KL, Hueston CM, Bishop C (2013) Effects of 5-HT1A receptor stimulation on $\mathrm{D} 1$ receptor agonist-induced striatonigral activity and dyskinesia in hemiparkinsonian rats. ACS Chem Neurosci 4, 747-760.

[61] Lindenbach D, Palumbo N, Ostock CY, Vilceus N, Conti MM, Bishop C (2015) Side effect profile of 5-HT treatments for Parkinson's disease and L-DOPA-induced dyskinesia in rats. $\mathrm{Br} \mathrm{J}$ Pharmacol 172, 119-130.

[62] Dupre KB, Eskow KL, Barnum CJ, Bishop C (2008) Striatal 5-HT1A receptor stimulation reduces $\mathrm{D} 1$ receptor-induced dyskinesia and improves movement in the hemiparkinsonian rat. Neuropharmacology 55, 1321-1328.

[63] Iravani MM, Tayarani-Binazir K, Chu WB, Jackson MJ, Jenner P (2006) In 1-methyl-4-phenyl1,2,3,6-tetrahydropyridine-treated primates, the selective 5-hydroxytryptamine 1a agonist (R)-(+)-8-OHDPAT inhibits levodopa-induced dyskinesia but only with $\backslash$ increased motor disability. J Pharmacol Exp Ther 319, 1225-1234.

[64] Bezard E, Munoz A, Tronci E, Pioli EY, Li Q, Porras G, Bjorklund A, Carta M (2013) Antidyskinetic effect of anpirtoline in animal models of L-DOPA-induced dyskinesia. Neurosci Res 77, 242-246.

[65] Bezard E, Tronci E, Pioli EY, Li Q, Porras G, Bjorklund A, Carta M (2013) Study of the antidyskinetic effect of eltoprazine in animal models of levodopa-induced dyskinesia. Mov Disord 28, 1088-1096.

[66] Bara-Jimenez W, Bibbiani F, Morris MJ, Dimitrova T, Sherzai A, Mouradian MM, Chase TN (2005) Effects of serotonin 5-HT1A agonist in advanced Parkinson's disease. Mov Disord 20, 932-936.

[67] Goetz CG, Damier P, Hicking C, Laska E, Muller T, Olanow CW, Rascol O, Russ H (2007) Sarizotan as a treatment for dyskinesias in Parkinson's disease: a double-blind placebocontrolled trial. Mov Disord 22, 179-186.

[68] Olanow CW, Agid Y, Mizuno Y, Albanese A, Bonuccelli U, Damier P, De Yebenes J, Gershanik $O$, Guttman $M$, Grandas F, Hallett M, Hornykiewicz O, Jenner $P$, Katzenschlager $R$, Langston WJ, LeWitt P, Melamed E, Mena MA, Michel PP, Mytilineou C, Obeso JA, Poewe W, Quinn N, Raisman-Vozari R, Rajput AH, Rascol O, Sampaio C, Stocchi F (2004) Levodopa in the treatment of Parkinson's disease: current controversies. Mov Disord 19, 997-1005.

[69] Kannari K, Kurahashi K, Tomiyama M, Maeda T, Arai A, Baba M, Suda T, Matsunaga M (2002) [Tandospirone citrate, a selective 5-HT1A agonist, alleviates L-DOPA-induced dyskinesia in patients with Parkinson's disease]. No To Shinkei 54, 133-137.

[70] Colom M, Vidal B, Zimmer L (2019) Is There a Role for GPCR Agonist Radiotracers in PET Neuroimaging? Front Mol Neurosci 12, 255.

[71] Shalgunov V, van Waarde A, Booij J, Michel MC, Dierckx R, Elsinga PH (2019) Hunting for the high-affinity state of G-protein-coupled receptors with agonist tracers: Theoretical and practical considerations for positron emission tomography imaging. Med Res Rev 39, $1014-$ 1052.

[72] Laruelle M (2000) Imaging synaptic neurotransmission with in vivo binding competition techniques: a critical review. J Cereb Blood Flow Metab 20, 423-451.

[73] Paterson LM, Tyacke RJ, Nutt DJ, Knudsen GM (2010) Measuring endogenous 5-HT release by emission tomography: promises and pitfalls. J Cereb Blood Flow Metab 30, 1682-1706. 
[74] Lee JH, Ryu YH, Lyoo CH, Choi SH, Kim JJ, Choi JY (2016) Optimal timing of [(1)(8)F]Mefway PET for imaging the serotonin $1 \mathrm{~A}$ receptor in healthy male subjects. Appl Radiat Isot 107, 127-132.

[75] Lee M, Ryu YH, Cho WG, Kang YW, Lee SJ, Jeon TJ, Lyoo CH, Kim CH, Kim DG, Lee K, Choi TH, Choi JY (2015) Relationship between dopamine deficit and the expression of depressive behavior resulted from alteration of serotonin system. Synapse 69, 453-460.

[76] Miguelez C, Benazzouz A, Ugedo L, De Deurwaerdere P (2017) Impairment of Serotonergic Transmission by the Antiparkinsonian Drug L-DOPA: Mechanisms and Clinical Implications. Front Cell Neurosci 11, 274.

[77] Assie MB, Cosi C, Koek W (1999) Correlation between low/high affinity ratios for 5-HT(1A) receptors and intrinsic activity. Eur J Pharmacol 386, 97-103.

[78] Gagnon D, Eid L, Coude D, Whissel C, Di Paolo T, Parent A, Parent M (2018) Evidence for Sprouting of Dopamine and Serotonin Axons in the Pallidum of Parkinsonian Monkeys. Front Neuroanat 12, 38.

[79] Vegas-Suarez S, Aristieta A, Requejo C, Bengoetxea H, Lafuente JV, Miguelez C, Ugedo L (2021) The effect of 5-HT1A receptor agonists on the entopeduncular nucleus is modified in 6-hydroxydopamine-lesioned rats. Br J Pharmacol.

[80] Politis M, Pagano G, Niccolini F (2017) Imaging in Parkinson's Disease. Int Rev Neurobio/ 132, 233-274.

[81] Navailles S, Bioulac B, Gross C, De Deurwaerdere P (2010) Serotonergic neurons mediate ectopic release of dopamine induced by L-DOPA in a rat model of Parkinson's disease. Neurobiol Dis 38, 136-143.

[82] Navailles S, Bioulac B, Gross C, De Deurwaerdere P (2011) Chronic L-DOPA therapy alters central serotonergic function and L-DOPA-induced dopamine release in a region-dependent manner in a rat model of Parkinson's disease. Neurobiol Dis 41, 585-590.

[83] Stansley BJ, Yamamoto BK (2015) Behavioral impairments and serotonin reductions in rats after chronic L-dopa. Psychopharmacology (Berl) 232, 3203-3213.

[84] Borah A, Mohanakumar KP (2007) Long-term L-DOPA treatment causes indiscriminate increase in dopamine levels at the cost of serotonin synthesis in discrete brain regions of rats. Cell Mol Neurobiol 27, 985-996.

[85] Stansley BJ, Yamamoto BK (2014) Chronic L-dopa decreases serotonin neurons in a subregion of the dorsal raphe nucleus. J Pharmacol Exp Ther 351, 440-447.

[86] Lindgren HS, Andersson DR, Lagerkvist S, Nissbrandt H, Cenci MA (2010) L-DOPA-induced dopamine efflux in the striatum and the substantia nigra in a rat model of Parkinson's disease: temporal and quantitative relationship to the expression of dyskinesia. J Neurochem 112, 1465-1476.

[87] Biggs CS, Starr MS (1997) Dopamine and glutamate control each other's release in the basal ganglia: a microdialysis study of the entopeduncular nucleus and substantia nigra. Neurosci Biobehav Rev 21, 497-504.

[88] Eskow Jaunarajs KL, Angoa-Perez M, Kuhn DM, Bishop C (2011) Potential mechanisms underlying anxiety and depression in Parkinson's disease: consequences of I-DOPA treatment. Neurosci Biobehav Rev 35, 556-564.

[89] Rylander D, Parent M, O'Sullivan SS, Dovero S, Lees AJ, Bezard E, Descarries L, Cenci MA (2010) Maladaptive plasticity of serotonin axon terminals in levodopa-induced dyskinesia. Ann Neurol 68, 619-628.

[90] Bantick RA, Montgomery AJ, Bench CJ, Choudhry T, Malek N, McKenna PJ, Quested DJ, Deakin JF, Grasby PM (2004) A positron emission tomography study of the 5-HT1A receptor in schizophrenia and during clozapine treatment. J Psychopharmacol 18, 346-354.

[91] Bantick RA, Rabiner EA, Hirani E, de Vries MH, Hume SP, Grasby PM (2004) Occupancy of agonist drugs at the 5-HT1A receptor. Neuropsychopharmacology 29, 847-859.

[92] Rabiner EA, Wilkins MR, Turkheimer F, Gunn RN, Udo de Haes J, de Vries M, Grasby PM (2002) 5-Hydroxytryptamine1A receptor occupancy by novel full antagonist 2-[4-[4-(7-chloro- 
2,3-dihydro-1,4-benzdioxyn-5-yl)-1-piperazinyl] butyl]-1,2-benzi sothiazol-3-(2H)-one-1,1dioxide: a[11C][0-methyl-3H]-N-(2-(4-(2-methoxyphenyl)-1-piperazinyl)ethyl)- $\mathrm{N}$-(2-pyridinyl )cyclohexanecarboxamide trihydrochloride (WAY-100635) positron emission tomography study in humans. J Pharmacol Exp Ther 301, 1144-1150.

[93] Rabiner EA, Messa C, Sargent PA, Husted-Kjaer K, Montgomery A, Lawrence AD, Bench CJ, Gunn RN, Cowen P, Grasby PM (2002) A database of [(11)C]WAY-100635 binding to 5-HT(1A) receptors in normal male volunteers: normative data and relationship to methodological, demographic, physiological, and behavioral variables. Neuroimage 15, 620-632.

[94] Rabiner EA, Gunn RN, Wilkins MR, Sedman E, Grasby PM (2002) Evaluation of EMD 128130 occupancy of the 5-HT1A and the D2 receptor: a human PET study with [11C]WAY-100635 and [11C]raclopride. J Psychopharmacol 16, 195-199. 